\title{
RETORIKA DALAM DEBAT CALON GUBERNUR DAN WAKIL GUBERNUR KALIMANTAN SELATAN TAHUN 2020
}

\section{RETORICS IN THE DEBATE OF THE GOVERNOR AND DEPUTY GOVERNOR CANDIDATES OF SOUTH KALIMANTAN IN 2020}

\author{
Ardiansyah \\ SMP Negeri 1 Pulau Laut Barat \\ Jalan Transmigrasi, RT. 05 RW. 03, Desa Lontar Timur, Kecamatan Pulaulaut Barat, \\ Kabupaten Kotabaru \\ Ponsel: 085252309951; Pos-el: ardianmandar@gmail.com
}

Naskah Diterima Tanggal: 24 Desember 2020; Direvisi Akhir Tanggal: 14 Juni 2021; Disetujui Tanggal: 25 Juni 2021 DOI: https://doi.org/10.26499/mab.v15i1.434

\begin{abstract}
Abstrak
Manusia tidak bisa terlepas dari kegiatan berbahasa dalam kehidupan sehari-hari. Kegiatan berbahasa dibagi menjadi dua, yakni kegiatan berbahasa lisan dan kegiatan berbahasa tulis. Tujuan penelitian ini adalah untuk mendeskripsikan pengorganisasian tuturan dan pemilihan kata calon gubernur dan wakil gubernur dalam Debat Pemilihan Gubernur dan Wakil Gubernur Kalimantan Selatan Tahun 2020. Penelitian ini merupakan penelitian deskriptif kualitatif. Penelitian dibatasi pada pengorganisasian tuturan dan pemilihan kata. Penelitian ini menggunakan metode dokumentasi dan instrumen penelitian menggunakan kartu data. Hasil penelitian ini menunjukkan bahwa saat berbicara, penutur menerapkan empat aspek pengorganisasian tuturan, yang meliputi: 1) prinsip organisasi tuturan (prinsip kesatuan, prinsip koherensi, prinsip penekanan), 2) organisasi tuturan (bagian awal, bagian tengah, bagian akhir), 3) pola organisasi tuturan (pola topikal, pola sebab-akibat, dan pola pemecahan masalah), dan 4) pengembangan tuturan (teknik narasi, teknik induktif, teknik deduktif, teknik sebab-akibat, teknik menjelaskan dasar sebelum atau sesudah pernyataan, teknik analogi teknik klimaks,). Terkait dengan pemilihan kata, hasil penelitian ini menunjukkan bahwa penutur menerapkan aspek pemilihan kata yang meliputi penggunaan kata yang jelas (menggunakan kata-kata sederhana, kata-kata yang spesifik, menggunakan kata secara hemat), penggunaan kata yang tepat, dan penggunaan kata yang menarik (menggunakan kata yang berona, dan kata-kata tindak, memilih kata yang langsung menyentuh diri mitra tutur).
\end{abstract}

Kata kunci: retorika; calon gubernur; pengorganisasian tuturan; pemilihan kata 


\begin{abstract}
Humans cannot be separated from language in any kind of activity in their daily life. Language activities are divided into two; spoken and activities. The purpose of this study is to describe the speech organization and word selection of candidates for governor and vice governor in the 2020 South Kalimantan Governor and Vice Governor Election Debate. This research is a qualitative-descriptive study. The research is limited to speech organization and word choice. This study useS documentation methods and the research instrument used in this study was data cards. The results of this study indicated that in spoken language, the speakers applied four aspects of speech organization, which included: 1) speech organization principles (unity principle, coherence principle, emphasize principle), 2) speech organization (early part, middle part, end part), 3) speech organization pattern (topical pattern, causal pattern, and problem solving pattern), and 4) speech development (narrative technique, inductive technique, deductive technique, cause-and-effect techniques, techniques to explain the basis before or after statements, analogy techniques, climax techniques,). Regarding word choice, the results of this study indicated that the speakers applied word selection aspects which included clear word use (used simple words, specific words, words sparingly), used appropriate words, and interesting words. (used colored words, and action words, chose words that directly touch the speech interlocutor).
\end{abstract}

Keywords: rhetoric; candidate for governor; organizing speech; word selection

\section{Pendahuluan}

Manusia tidak bisa terlepas dari kegiatan berbahasa dalam kehidupan sehari-hari. Kegiatan berbahasa dibagi menjadi dua, yakni kegiatan berbahasa lisan dan kegiatan berbahasa tulis. Namun, di dalam keseharian manusia cenderung menggunakan bahasalisan untuk berkomunikasi. "Dalam peristiwa komunikasi, tujuan utama komunikator adalah menyampaikan pesan yang diharapkan dapat diketahui, dipahami, dan dapat diterima oleh komunikan" (Martha, 2012: 6). Berdasarkan pendapat tersebut, proses komunikasi yang baik dan efektif tidak hanya berkaitan dengan apa yang dikatakan seseorang tetapi juga bagaimana seseorang itu mengatakannya. Jadi, sebelum pesan itu disampaikan, pesan diolah dan diorganisasikan dalam pikiran sebelum dilontarkan melalui alat ucap dalam bentuk kata-kata terlebih dahulu sehingga penerima pesan mampu menangkap dengan baik maskud yang ingin disampaikan olehkomunikator.

Manusia cenderung menggunakan bahasa lisan dalam berkomunikasi maka komunikasi tersebut dapat dilakukan melalui kegiatan bertutur. Ada kemungkinan bahwa kemampuan bertutur atau berbicara merupakan bakat namun kepandaian berbicara yang baik memerlukan pengetahuan dan latihan (Sutrisno dan Wiendijarti, 2014: 71). Dengan kata lain, setiap orang memiliki kemampuan untuk bertutur atau berbicara. Bahkan, ada yang memang memiliki bakat sejak kecil. Namun, pengetahuan 
yang memadai juga menjadi faktor pendukung kemampuan berbicara seseorang sehingga kemampuan bertuturnya juga semakin baik. Meski demikian, terkadang ada orang yang mengetahui topik pembicaraan ataupun memiliki sebuah gagasan, namun tidak mampu membahasakan atau mengkomunikasikannya secara lisan kepada orang lain dengan baik

Pada akhir bulan September hingga awal Desember 2020, Provinsi Kalimantan Selatan tengah masuk ke dalam pesta demokrasi yang tengah hangatnya karena pada bulan tersebut memasuki tahapan kampanye terbuka. Hal tersebut dikarenakan adanya pemilihan Gubernur dan Wakil Gubernur Kalimantan Selatan Tahun 2020. Ini merupakan pemilihan gubernur keempat bagi Kalimantan Selatan yang dilakukan secara langsung menggunakan sistem pencoblosan. Pemilihan gubernur tersebut diikuti oleh dua pasangan calon gubernur dan wakil gubernur, yaitu: pasangan $\mathrm{H}$. Sahbirin Noor, S.Sos., M.H. dengan H. Muhidin dan Prof. H. Denny Indrayana, S.H., LL.M., Ph.D. dengan Drs. H. Difriadi.

Sebelum diselenggarakan pemilihan gubernur tersebut, KPU Provinsi Kalimantan Selatan menyelenggarakan debat resmi calon Gubernur dan Wakil Gubernur Kalimantan Selatan. Debat tersebut diselenggarakan sebanyak tiga putaran, yakni pada tanggal 4 November 2020 debat calon gubernur, 18 November 2020 debat calon wakil gubernur, dan 28 November 2020 debat calon gubernur dan wakil gubernur. Debat ini dipublikasikan di beberapa stasiun TV lokal dan kanal YouTubeKPU Provinsi Kalimantan Selatan sehingga banyak orang yang dapat menyaksikan. Selain hal tersebut, kualitas dari para kandidat atau orang yang dicalonkan untuk menjadi gubernur juga menjadi alasan pemilihan debat ini untuk dijadikan subjek penelitian.

Dikutip dari laman website KPU Provinsi Kalimantan Selatan (2020), para kandidat calon Gubernur dan Wakil Gubernur Kalimantan Selatan memiliki keunggulannya masing-masing, seperti $\mathrm{H}$. Sahbirin Noor, S.Sos., M.H. adalah seseorang yang telah memiliki pengalaman sebagai Gubernur Kalimantan Selatan dan H. Muhidin seorang mantan Wali Kota Banjarmasin. Kemudian Prof. H. Denny Indrayana, S.H., LL.M., Ph.D. pernah menjabat sebagai Wakil Menteri Hukum dan HAM, yang juga merupakan Guru Besar Fakultas Hukum Universitas Gajah Mada dan Drs. H. Difriadi seorang mantan Wakil Bupati Tanah Bumbu. Martha (2014), menyatakan bahwa "salah satu unsur pendukung retorika adalah 
pengetahuan yang memadai. Jika tidak ditunjang oleh pengetahuan yang memadai, penyampai pesan bisa menjadi tukang bual". Berdasarkan hal tersebut, maka seorang yang berbicara harus memiliki pengetahuan yang cukup terhadap apa yang ingin disampaikan. Berdasarkan pengalaman kedua calon tersebut, maka debat pemilihan gubernur ini dinilai menarik untukditeliti.

Selain dilihat dari pengalaman, masing-masing calon gubernur dan wakil gubernur ini juga memiliki karakteristik yang berbeda, salah satunya terlihat dari strategi komunikasi atau cara bicaranya. Seperti H. Sahbirin Noor, S.Sos., M.H. yang memiliki cara berbicara yang menggunakan bahasa sederhana, dengan pola berbicara yang cenderung spontan sehingga program-program yang disampaikan bisa lebih dimengerti oleh semua kalangan. Namun, gaya bahasanya yang spontan ini jugamenyebabkan sisi blundernya lebih besar.

Jika H. Sahbirin Noor, S.Sos., M.H. memiliki cara berbicara yang sederhana, Prof. H. Denny Indrayana, S.H., LL.M., Ph.D. memiliki gaya bicara yang dibungkus dengan indah dalam rangkaian kata-kata yang santun. Merangkai kalimat yang memotivasi dan menginspirasi. Namun, pola komunikasi ini juga dinilai memiliki kelemahan. Cara bicaranya dianggap terlalu high context sehingga tidak banyak masyarakat kecil yang memahami gaya bicaranya.

Adapun penelitian sejenis yang peneliti temukan, yaitu Humaidi (2016) yang melakukan penelitian dengan judul "Struktur Teks, Kognisi Sosial, dan Dimensi Sosial Pidato Susilo Bambang Yudhoyono". Kemudian penelitian sejenis juga dilakukan oleh Kusmiati, dkk (2017) yang melakukan penelitian denga judul “Analisis Retorika Calon Gubernur pada Debat Pemilihan Gubernur DKI Jakarta Tahun 2017" Penelitian sejenis juga dilakukan oleh Ardiansyah, (2017) yang melakukan penelitian dengan judul "Analisis Retorika Basuki Tjahaja Purnama dalam Kampanye Rakyat Pemilihan Kepala Daerah Khusus Ibukota Jakarta di Rumah Lembang 2017”

Walaupun terdapat penelitian serupa, penelitian ini memiliki beberapa perbedaan dengan penelitian terdahulu. Pertama, pada penelitian Humaidi (2016), meneliti struktur teks, kognisi sosial, dan dimensi sosial pada pidato Susilo Bambang Yudhoyono. Pada penelitian tersebut objek yang diteliti juga berbeda. Penelitian tersebut meneliti struktur teks, kognisi sosial, dan dimensi sosial dalam pidato Susilo Bambang Yudhoyono, sedangkan pada penelitian ini dalam sebuah debat. Kedua, penelitian Kusmiati, dkk (2017) meneliti Retorika Calon Gubernur pada Debat Pemilihan 
Gubernur DKI Jakarta Tahun 2017, Ketiga Penelitian Ardiansyah, (2017) meneliti Retorika Basuki Tjahaja Purnama dalam Kampanye Rakyat Pemilihan Kepala Daerah Khusus Ibukota Jakarta di Rumah Lembang 2017, sedangkan pada penelitian ini, retorika yang diteliti merupakan retorika dalam debat Gubernur dan Wakil Gubernur Kalimantan Selatan Tahun 2020.

Berdasarkan uraian di atas, masalah yang menjadi fokus penelitian dalam penelitian ini adalah bagaimanakah pengorganisasian tuturan calon gubernur dan wakil gubernur dalam Debat Pemilihan Gubernur dan Wakil Gubernur Kalimantan Selatan Tahun 2020 dan 2) bagaimanakah pemilihan kata calon gubernur dan wakil gubernur dalam Debat Pemilihan Gubernur dan Wakil Gubernur Kalimantan Selatan Tahun 2020.

Adapun tujuan penelitian ini adalah 1) untuk mendeskripsikan pengorganisasian tuturan calon gubernur dan wakil gubernur dalam Debat Pemilihan Gubernur dan Wakil Gubernur Kalimantan Selatan Tahun 2020 dan 2) mendeskripsikan pemilihan kata calon gubernur dan wakil gubernur dalam Debat Pemilihan Gubernur dan Wakil Gubernur Kalimantan Selatan Tahun 2020.

\section{Landasan Teori}

Retorika dalam perkembangan selanjutnya sering diidentikkan dengan public speaking (kemampuan berbicara di depan umum). banyak juga yang berpendapat bahwa retorika tidak hanya kemampuan berbicara di hadapan publik, tetapi juga mencakup seni menulis. itulah sebabnya para ahli komunikasi lebih cenderung menempatkan retorika sebagai gabungan seni berbicara di hadapan orang banyak dan pengetahuan untuk meyakinkan orang lain terhadap suatu masalah melalui pendekatan persuasi (Tasmara, 2014: 136).

"Esensi retorika adalah upaya-upaya yang dilakukan penutur (pada bahasa lisan) dan penulis (pada bahasa tulisan) dalam memilih bentuk ungkapan yang dianggap paling efektif untuk menarik perhatian pendengar atau pembaca" (Martha, 2014: 3). Jadi jika dikaitkan dengan kegiatan berkomunikasi, penutur tidak hanya sekadar menyampaikan sebuah pesan, melainkan juga memikirkan bentuk ungkapan, seperti pemilihan materi bahasa agar tutur yang disampaikan menjadi lebih efektif dan tepatsasaran.

Retorika digunakan dalam bidang atau lingkungan yang sangat luas. Martha (2014) menyatakan bahwa retorika dapat digunakan dalam bidang seni, pendidikan, perdagangan, politik, dan lain-lain. Retorika di dalam bidang politik dimanfaatkan untuk melakukan propaganda-propaganda politik, kampanye 
Retorika dalam Debat...

menjelang pemilu dalam negara yang menganut pemanfaatan demokrasi. Politik memanfaatkan retorika untuk mempengaruhi rakyat dengan materi bahasa, ulasan-ulasan, dan gaya bertutur yang meyakinkan dan mencekam perhatian.

Di dalam dunia politik kita tidak asing dengan debat. Secara umum, definisi debat adalah salah satu bentuk seni berbicara dialogika. "Debat pada hakikatnya adalah saling adu argumentasi antarpribadi atau antarkelompok manusia dengan tujuan mencapai kemenangan untuk satu pihak"(Hendrikus, 1991: 120). Debat sangat populer digunakan dalam politik, terlebih menjelang pemilihan umum dan biasanya dilakukan untuk kampanye politik. Tarigan (2015: 94) meyatakan bahwa, "Debat bersama memudahkan para pemilih atau pemberi suara mendengar para calon yang bertentangan saling mempertahankan pendapat dan menyerang kelemahan lawan”. Jadi, debat yang dilakukan dalam kampanye politik, memudahkan calon pemilih untuk mengetahui rencana kerja para calon apabilaterpilih.

Berdasarkan hal tersebut, retorika memiliki peran penting di dalam debat. Dengan kata lain, retorika menjadi penghubung dalam penyampaian ide, pesan, maupun gagasan yang disampaikan dengan bahasa sebagai medianya ketika berdebat. Sebagai sarana bertutur efektif, retorika sendiri memiliki beberapa aspek. Di antaranya, pengorganisasian tuturan dan pemilihan materi bahasa. Pengorganisasian tuturan sangat penting untuk dilakukan penutur ketika melakukan debat agar ide-ide utama tuturan dapat tersampaikan dengan jelas kepada mitratutur.

Selain pengorganisasian tuturan, pemilihan materi bahasa juga menjadi hal yang penting dilakukan ketika melakukan kegiatan debat. Perlunya pemilihan materi bahasa disebabkan oleh adanya banyak materi bahasa yang tidak cocok digunakan untuk segala situasi (Sudiana, 2007: 128). Berdasarkan hal itu, pemilihan materi bahasa harus disesuaikan dengan kondisi dan situasi ketika peristiwa bertutur dilakukan. Pemilihan materi bahasa sendiri terbagi menjadi dua, yakni pemilihan kata dan pemilihan bahasa figuratif. Namun dari kedua aspek pemilihan materi bahasa, peneliti membatasi masalah hanya pada pemilihan kata. Pemilihan kata diperlukan sebagai wadah untuk penutur menyampaikan ide dan gagasannya dengan jelas sehingga tidak terjadi kesalahpahaman antara penutur dengan lawanbicara. 


\section{Metode Penelitian}

Penelitian ini adalah penelitian deksriptif kualitatif. Data yang dideskpripsikan melalui penelitian ini adalah data yang berkaitan dengan masalah yang dikaji, yaitu pengorganisasian tuturan dan pemilihan kata oleh calon Gubernur dan Wakil Gubernur Kalimantan Selatan pada debat pemilihan Gubernur dan Wakil Gubernur Kalimantan Selatan Tahun 2020. Namun, pada penelitian ini, debat yang dianalisis dibatasi hanya pada putaranketiga. Kemudian, data yang telah diperoleh dideskripsikan secara kualitatif atau dalam bentuk kata-kata. Subjek dalam penelitian ini adalah calon gubernur dalam debat pemilihan Gubernur dan Wakil Gubernur Kalimantan Selatan Tahun 2020. Sedangkan objek dalam penelitian ini adalah retorika calon gubernur dalam debat calonGubernur dan Wakil Gubernur Kalimantan Selatan. Dalam hal ini peneliti membatasi masalah hanya pada pengorganisasian tuturan dan pemilihan kata.

Metode pengumpulan data yang digunakan dalam penelitian ini adalah metode dokumentasi. Pada metode dokumentasi ini, peneliti mengumpulkan video rekaman debat pemilihan Gubernur dan Wakil Gubernur Kalimantan Selatan putaran ketiga yang terdiri dari. Setelah video-video tersebut terkumpul, selanjutnya peneliti mentranskripsikan debat tersebut ke dalam bentuk tulisan untuk mempermudah analisis data. Dalam penelitian ini, peneliti menggunakan instrumen berupa kartu data untuk mendapatkan data yang sesuai dengan rumusan masalah. Peneliti mencatat data yangdidalamnyaterdapat pengorganisasian tuturan dan pemilihan kata calon gubernur pada debat pemilihan Gubernur dan Wakil Gubernur Kalimantan Selatan tahun 2020. Pada penelitian ini, peneliti menggunakan model analisis data Miles dan Huberman. Miles dan Huberman (dalam Sugiyono, 2009: 246) membagi tahap analisis data menjadi tiga, yakni reduksi data, penyajian data, dan verifikasi atau penarikan simpulan.

\subsection{Reduksi Data}

Reduksi data merupakan proses pemilihan, pemusatan perhatian pada penyederhanaan, pengabstrakan, dan transformasi data kasar yang muncul dari data-data lapangan.

\subsection{Penyajian Data}

Penyajian data merupakan salah satu kegiatan dalam pembuatan laporan hasil penelitian yang telah dilakukan agar data yang telah dikumpulkan dapat dipahami dan dianalisis sesuai dengan tujuan yang diinginkan

\subsection{Verifikasi atau Penarikan Simpulan \\ Setelah melakukan tahap pengolahan} data di atas, hal selanjutnya yang di 
Retorika dalam Debat...

lakukan adalah menarik simpulan.

tuturan, penutur (calon gubernur)

Simpulan yang dituliskan mencakup

informasi-informasi penting dalam

penelitianmu secara garis besar. Simpulan

tersebut juga harus dalam bahasa yang

mudah dimengerti pembaca dan tidak berbelit-belit.

\section{Pembahasan}

Dalam penelitian ini, diperoleh hasil penelitian berupa pengorganisasian tuturan dan pemilihan kata calon gubernur pada debat pemilihan Gubernur dan Wakil Gubernur Kalimantan Selatan tahun 2020. Berdasarkan data yang telah diperoleh dan dianalisis, ditemukan fakta bahwa penutur menerapkan seluruh aspek pengorganisasian tuturan dan aspek pemilihan kata.

\subsection{Pengorganisasian Tuturan}

Ditinjau dari organisasi tuturan, tuturan yang disampaikan oleh calon gubernur pada Debat Pemilihan Gubernur dan Wakil Gubernur Kalimantan Selatan tahun 2020 sudah mencakup tiga bagian utama organisasi tuturan, yakni bagian awal, bagian tengah, dan bagian akhir. untuk mengawali tuturan, Sudiana (2007: 92), menyatakan bahwa ada beberapa petunjuk yang dapat dipertimbangkan dalam mengawali suatu tuturan yang disesuaikan dengan jenis, tujuan, dan ide sentral tuturan. Hasil penelitian ini menunjukkan bahwa, dalam memulai

mengawali tuturan dengan cara yang cukup bervariasi, meliputi langsung menyebutkan persoalan, mengawali dengan pernyataan yang mengejut-kan, menceritakan pengalaman pribadi, melukiskan latar belakang masalah, menghubungkan dengan peristiwa yang mutakhir atau aktual. Hasil analisis tersebut juga sejalan dengan teori yang disampaikan oleh Rakhmat (2012: 53) yang menyatakan bahwa ada beragam cara yang dapat dilakukan oleh penutur dalam mengakhiri tuturan, di antaranya langsung menyebutkan persoalan, mengawali dengan pernyataan yang mengejutkan, menceritakan pengalaman pribadi, melukiskan latar belakang masalah, menghubungkan dengan peristiwa yang mutakhir atau aktual. Berikut ini adalah analisis retorika dalam debat Calon Gubernur dan Wakil Gubernur Kalimantan Selatan Tahun 2020.

\subsubsection{Organisasi Tuturan Bagian Awal}

Pada penelitian ini ditemukan fakta bahwa penutur cenderung memulai tuturannya dengan cara melukiskan latar belakang masalah. Hal ini terbukti dari jumlah data yang diperoleh berdasarkan analisis cara penutur mengawali tuturan lebih banyak dengan cara melukiskan latar belakang masalah dibandingkan dengan cara lainnya. Berikut ini adalah 
salah satu contoh data yang menunjukkan bahwa penutur memulai tuturannya dengan cara melukiskan latar belakang masalah.

"Produksi padi disambat (disebutkan) sebenarnya dalam 5 tahun terakhir produksi padi kita turun dua setengah kali lipat di tahun 20162,3 juta ton dan di tahun 2020 belum sampai akhir datanya adalah 991.773 ton ini menyebabkan petani kita memang akan kesulitan secara ekonomi. Coba lihat nelayan anggaran kelautan dan perikanan Kalsel tahun 2020 menurun $82 \%$ dari 18,2 miliar di tahun 2016 menjadi 3,4 miliar di tahun 2020 intinya ini harus diluruskan prinsip good governance harus diletakkan keberpihakan harus diwujudkan kepada sebagian besar masyarakat Kalimantan Selatan" (Prof. H. Denny Indrayana, S.H., LL.M., Ph.D.: Sesi 1, Debat Pilgub Kalsel Putaran 3)

"Kita tahu hari ini di dunia sedang mendapatkan musibah dan sampai detik ini masih tidak ada satupun di dunia sekelas Amerika negara maju tidak ada yang bisa memastikan tidak ada.Kita tahu ketika Covid19 masuk ke Indonesia datang dari sebuah negeri yang bernama Wuhan masuk ke Indonesia terus sampai ke Kalimantan Selatan. Apa yang terjadi kita, semua kita rasakan, saya sering bilang bahwa Covid19 datang seperti hantu sehingga kondisi kita pada saat awal masuk ke Kalimantan Selatan semua kegiatan berhenti termasuk hari itu di Kiram ada kegiatan seKalimantan berhenti.Semua menghantui kita, semua kebetulan kita sebagai kepala daerah, hal itu segera mengumpulkan Forkopimda (H. Sahbirin Noor, S.Sos.,M.H.:
Sesi 2, Debat Pilgub Kalsel Putaran 3)

Pada data tersebut, penutur mengawali tuturannya dengan cara melukiskan terlebih dahulu latar belakang persoalan. Latar belakang persoalan tersebut berupa masalah ketidak berpihakan anggaran, dapat dilihat pada tuturan Haji Denny. Kemudian, pada tuturan Paman Birin terlihat latar belakang masalah berupa Covid19. Berangkat dari masalah tersebutlah penutur menyampaikan hal-hal yangakan dilakukan untuk mengatasi persoalan tersebut.

\subsubsection{Organisasi Tuturan Bagian Tengah \\ Pada bagian tengah, penutur} menguraikan secara rinci pokok tuturan yang disampaikan. Berdasarkan hal tersebut, data yang ditemukan terkait dengan organisasi tuturan bagian tengah sudah sesuai dengan teori yang menyatakan bahwa, Pada bagian tengah atau isi tuturan berisi uraian yang rinci mengenai perihal pokok tuturan (Sudiana, 2007: 96).Berikut ini adalah contoh tuturan bagian tengah yang disampaikan oleh penutur.

"Jika Tuhan memberikan kesempatan, Jika Allah Subhanahu Wa Ta'ala memberikan kesempatan bagi kami untuk mengabdi membangun Banua, maka Kami Insya Allah akan menjadi gubernur buat semua, tetapi bukan berarti kita tidak berpihak. Keberpihakan harus diwujudkan terutama bagi 
dangsanak (saudara) dan sanak kita yang kurang beruntung.Karena itu, politik anggaran kami di 4 bidang atau 3 bidang tadi kesehatan terkait dengan sumber daya alam terkait dengan energi dan terkait dengan bidang-bidang yang tadi kita diskusikan itu akan berpihak kepada kaum-kaum yang memang termarjinalkan. Itu akan terlihat dalam anggaran dan itu akan terealisasi dalam program-program yang Insya Allah akan diturunkan dengan prinsip-prinsip anti korupsi" (Prof. H. Denny Indrayana, S.H., LL.M., Ph.D.: Sesi 1, Debat Pilgub Kalsel Putaran 3).

"Saya minta Bapak Kapolda keluarkan perwira yang terbaik dari Polda yang terbaik dari Korem, dari Kajati, pokoknya semua kita ngumpul, kemudian saya minta ahli biologi yang mengerti tentang Covid19. Maka kita setelah itu kita mengambil langkah-langkah, apa yang harus kita lakukan harus kita laksanakan, makhluk apa yang bernama Covid19 mencekam kita semua, terutama langkah yang kita ambil adalah menyelamatkan siapa saja yang terdampak oleh Covid19, baik dalam bidang kesehatan yang tadinya kita hanya punya ruangan 23 perbanyak karena kita tahu ini akan bertambah lebih banyak lagi." (H. Sahbirin Noor, S.Sos.,M.H.: Sesi 2, Debat Pilgub Kalsel Putaran 3)

Pada data tersebut, bagian tengah tuturan, penutur menguraikan bagian pokok dalam pembicaraan. Uraian tersebut berisi tentang penjabaran secara rinci tentang keberpihakan anggaran dan langkah mengatasi masalah Covid19.

\subsubsection{Organisasi Tuturan Bagian Akhir}

Pada bagian akhir tuturan,
Sudiana (2007: 97) menyatakan bahwa ada banyak teknik yang umum digunakan untuk mengakhiri atau menutup tuturan. Hasil penelitian ini menunjukkan bahwa penutur (calon gubernur) menutup tuturannya dengan cara yang bervariasi, meliputi menyatakan kembali gagasan utama dengan kalimat dan kata-kata yang berbeda, penutur mengakhiri tuturannya dengan cara menyimpulkan atau mengemukakan kembali ikhtisar pembicaraan, penutur mengakhiri tuturannya dengan cara mendorong audien untuk bertindak, penutur mengakhiri tuturan dengan klimaks, penutur mengakhiri tuturan dengan menerangkan maksud pribadi penutur yang sebenarnya. Hasil analisis tersebut, juga sejalan dengan teori yang disampaikan oleh Rakhmat (2012: 60) bahwa ada beragam cara yang dapat dilakukan oleh penutur dalam mengakhiri tuturan, di antaranya menyatakan kembali gagasan utama dengan kalimat dan katakata yang berbeda, penutur mengakhiri tuturannya dengan cara menyimpulkan atau mengemukakan kembali ikhtisar pembicaraan, penutur mengakhiri tuturan dengan cara mendorong audien untuk bertindak, penutur mengakhiri tuturan dengan klimaks, dan penutur mengakhiri tuturan dengan menerangkan maksud pribadi penutur yang sebenarnya. 
Dari kelima cara mengakhiri tuturan yang digunakan oleh penutur (calon gubernur), calon gubernur cenderung mengakhiri tuturannya dengan cara mengemukakan kembali ikhtisar pembicaraan dan menerangkan maksud pribadi penutur. Hal ini terbukti dari jumlah tuturan yang diperoleh berdasarkan analisis kelima cara penutur mengakhiri tuturan, lebih banyak dengan cara mengemukakan kembali ikhtisar pembicaraan dan menerangkan maksud pribadi penutur. Berikut ini adalah salah satu contoh data yang menunjukkan bahwa penutur mengakhiri tuturannya dengan cara menyimpulkan atau mengemukakan kembali ikhtisar pembicaraan dan menerangkan maksud pribadi penutur yang sebenarnya.

"Dangsanak Kalimantan Selatan sabarataan, warga banua, para petani, nelayan, buruh, petugaspetugas lapangan kesehatan, petugas-petugas pertanian, dan seluruh warga masyarakat, para alim ulama, tokoh agama, kami pada hari ini terakhir debat mudahan Allah meridhoi kita semua kita orangnya pintar tata krama kalau hendak Banua Sejahtera cucok (coblos) nang (yang) nomor dua. Banua kita sugihnya liwar (kaya raya) harus ditata dengan benar. Mari kita berikhtiar memilih gubernur hanyar (baru). Kita berniat sama-sama untuk menunjukkan apa yang terbaik bagi Kalimantan Selatan bagaimana data yang ada bagaimana faktanya sikap yang tidak punya kesempatan untuk menilai siapa yang pihak yang bisa pilih sebagai pemimpin terbaik Insyaallah di Banua. Kita tetap ingin menyampaikan satu kisah terkait dengan infrastruktur, dan sanak masalah jalan ini bukan masalah sederhana, ini bisa menjadi masalah nyawa. 20 Oktober 2020 Mustofa warga Desa Anduhum Kecamatan Balai Hulu Sungai Tengah, tewas karena kecelakaan demi menghindari jalan berlubang di turunan jembatan hauling $\mathrm{km} 88$ kabupaten Tapin. Muhammad Irfan warga Bangkal Cempaka Banjarbaru tewas terlindas truk tronton bermuatan berat ketika sepeda motornya oleng dan terjatuh menghindari lubang Jalan Sungai Besar Banjarbaru nyawa bukan masalah. 12.334 orang tewas akibat Lakalantas di Kalsel disebabkan karena jalan rusak dan human error. Data Polda Kalsel tanggal 3 Januari 2020. Jadi secara hukum pidana pun itu tanggung jawab kita yang punya pengatur kebijakan dan bisa dipenjara." (Prof. H. Denny Indrayana, S.H., LL.M., Ph.D.: Sesi 6, Debat Pilgub Kalsel Putaran 3).

"Kepada seluruh masyarakat yang ada di Kalimantan Selatan di 13 kabupaten kota, yang di pesisir pegunungan, dan lain sebagainya, dan tentunya kepada para habaib, para alim ulama, tokoh agama, tokoh masyarakat kita ucapkan di dalam kesempatan ini terima kasih dan penghargaan yang tidak terhingga yang selama ini telah memberikan pencerahan kepada masyarakat kita Kalimantan Selatan, juga pemerintahan Kalimantan Selatan sehingga di penghujung perintahan periode 2016-2021 ini sangat signifikan sekali.Ada 100 penghargaan Kalimantan Selatan, ini bukan main-main luar biasa sampai beberapa yang telah langsung diberikan oleh Presiden. Tapi 
nomor 2 berkata lain, seolah-olah hari ini Kalimantan Selatan info rusak, padahal justru sebaliknya.Luar biasa $\quad 100$ penghargaan tingkat nasional bukan mengada-ada." (H. Sahbirin Noor, S.Sos., M.H.: Sesi 6, Debat Pilgub Kalsel Putaran 3)

Pada data di atas, penutur mengakhiri tuturannya dengan cara menyimpulkan atau mengemukakan ikhtisar pembicaraan dan penutur mengakhiri tuturannya dengan cara menerangkan maksud pribadi penutur yang sebenarnya. Terkait dengan prinsip organisasi tuturan, Beebe dan Beebe, 2005 (dalam Sudiana, 2007: 100) menyatakan bahwa sebuah tuturan yang efektif harus memenuhi prinsip organisasi tuturan yang meliputi prinsip kesatuan, prinsip koherensi, dan prinsip penekanan. Teori yang sama juga disampaikan oleh Raymond S. Ross (dalam Rakhmat, 2012: 32) bahwa dalam menyusun pidato semua harus didasari dengan prinsip komposisi yang mempengaruhi seluruh organisasi pesan, meliputi prinsip kesatuan, pertautan, dan titik berat. Sejalan dengan teori tersebut, tuturan yang disampaikan oleh calon gubernur secara keseluruhan sudah menerapkan tiga prinsip organisasi tuturan.

\subsubsection{Prinsip Organisasi Tuturan (Prinsip Kesatuan, Koherensi, dan Penekanan)}

Terkait dengan prinsip organisasi tuturan, Beebe dan Beebe, 2005 (dalam
Sudiana, 2007: 100) menyatakan bahwa sebuah tuturan yang efektif harus memenuhi prinsip organisasi tuturan yang meliputi prinsip kesatuan, prinsip koherensi, dan prinsip penekanan. Teori yang sama juga disampaikan oleh Rakhmat (2012: 32) bahwa dalam menyusun pidato semua harus didasari dengan prinsip komposisi yang mempengaruhi seluruh organisasi pesan, meliputi prinsip kesatuan, pertautan, dan titik berat. Sejalan dengan teori tersebut, tuturan yang disampaikan oleh calon gubernur secara keseluruhan sudah menerapkan tiga prinsip organisasi tuturan.

Dari tiga prinsip organisasi tuturan, yang paling dominan digunakan oleh calon gubernur adalah prinsip koherensi. Hal tersebut dibuktikan dari jumlah data yang ditemukan mengandung prinsip koherensi. Hal ini disebabkan karena pada setiap tuturan harus menunjukkan jalinan yang saling bertautan antarkalimat dan gagasan sehingga tuturan menjadi logis dan dapat dimengerti oleh pendengar. Hal ini sejalan dengan pendapat Sudiana (2007: 101) yang menyatakan "prinsip koherensi mensyaratkan agar bagianbagian tuturan mencerminkan adanya jalinan yang runtut dan logis". Hal tersebut juga didukung oleh pendapat Rakhmat (2012: 33) yang menyatakan bahwa koherensi menyebabkan peralihan 
ide pembicaraan berjalan lancar. Apabila koherensi tersebut dihilangkan, khalayak tidak akan mampu menarik gagasan pokok dari seluruh pembicaraan.Berikut ini adalah salah satu contoh data yang menunjukkan adanya penggunaan prinsip koherensi pada tuturan calon gubernur.

"Jalan-jalan seluruhnya sekarang dalam kondisi rusak. Itu datanya BPS Kalimantan Selatan 2019, sedang rusak berat $58 \%$, jalan baik provinsi juga menurun dalam provinsi $756 \mathrm{KM}$. Jalan Raya provinsi itu 30 yang baik menurun $33 \%$, sepertiga Jalan provinsi rusak, $33 \%$ data BPS Kalimantan Selatan 2019, yang mungkin ada jalan hotmix minta izin Pak Sabirin menuju Kiram entah mengapa, karena itu menurut saya. Kalau kita bicara sumber, luar biasa potensinya pariwisata, sekali lagi kalau kita punya kebijakan untuk mengarahkan tidak hanya sumber daya alam tidak hanya bicara batubara lagi batubara lagi, maka kita akan melihat potensi wisata sungai kita luar biasa. Tetapi infrastruktur-infrastruktur yang berpihak pada kebutuhan rakyat itu menjadi penting, yang kemarin ketemu saya dari Kotabaru, pada keadaan saya di sana 30 tahun batubara dan tanahnya rusak bergelombang sangat banyak kita tentu prihatin." (Prof. H. Denny Indrayana, S.H., LL.M., Ph.D.: Sesi 3, Debat Pilgub Kalsel Putaran 3)

Data di atas mengandung prinsip koherensi berupa penggunaan kata penyambung "karena itu" . kata tersebut digunakan untuk menyambung bagian tuturan sebelumnya untuk menyatakan sebab akibat. Jika kata "karena itu" dihilangkan, maka bagian- bagian tuturan tersebut menjadi tidak runtut.

\subsubsection{Pola Organisasi Tuturan (Pola Topikal, Pemecahan Masalah, dan Sebab- Akibat)}

Ditinjau dari pola organisasi tuturan, Beebe dan Beebe, 2005 (dalam Sudiana, 2007: 107) menyatakan bahwa ada lima pola pengorganisasian tuturan yang dapat dipilh, yaitu (1) pola kronologis, (2) topikal, (3) spasial, (4) kausal, dan (5) pemecahan masalah. Kelima pola tersebut juga disampaikan oleh Rakhmat (2012:34) yang disebut sebagai organisasi pesan. Berdasarkan teori tersebut, tuturan calon gubernur hanya menggunakan beberapa pola dalam menyampaikan tuturannya, yakni pola topikal, pola pemecahan masalah, dan pola sebab-akibat. Dari ketiga pola organisasi tuturan tersebut, hasil penelitian ini menunjukkan bahwa penutur cenderung mengorganisasikan tuturannya dengan pola topikal. Berikut ini adalah salah satu contoh tuturan calon gubernur yang menggunakan polatopikal.

"Bicara energi terbarukan yang pertama kita karena perkebunan adalah salah satu juga potensial di Kalimantan Selatan, yaitu diantaranya perkebunan kelapa sawit. Nah ini merupakan salah satu potensi pengembangan energi baru ataupun terbarukanatau biosolar atau sawit. Kemudian kedua pembangkit listrik tenaga angin PLTA 70 megawatt dalam proses pembangunan di Tanah Laut jadi sangat mungkin." (H. Sahbirin Noor, S.Sos., M.H.: Sesi 4, Debat 
Pilgub Kalsel Putaran 3).

Pada data tersebut, penutur menggunakan pola topikal dalam menyampaikan gagasannya. Penutur menggunakan satu ide sentral yang sesuai dengan topik pembicaraan, yakni menjelaskan program unggulan yang dimiliki.

\subsubsection{Pengembangan Tuturan}

Ditinjau dari pengembangan tuturan, Sudiana, (2007: 117) menyatakan bahwa teknik yang lazim digunakan dalam pengembangan tuturan meliputi, 1) teknik induktif, (2) teknik deduktif, (3) teknik logikatoulmin, (4) teknik sebab-akibat, (5) tekniknarasi, (6) teknik pembandingan langsung, (7) teknik analogi, (8) teknik klimaks, (9) teknik menjelaskan dasar sebelum atau sesudah pernyataan, (10) teknik urutan spasial. Berdasarkan teori tersebut, tuturan calon gubernur sudah menggunakan teknik pengembangan tuturan dalam menyampaikan tuturan. Itu terbukti dari hasil analisis data yang diperoleh pada penelitian ini menunjukkan bahwa penutur menggunakan teknik yang bervariasi dalam setiap tuturan yang disampaikan. Berikut ini adalah salah satu contoh data yang ditemukan terkait teknik pengembangan tuturan menjelaskan dasar sebelum atau sesudahpernyataan.

"Kita tahu yang namanya membangun itu tidak seperti membalik telapak tangan, dia butuh proses mulai dari perencanaan musrenbang di tingkat kelurahan, di tingkat kecamatan, di tingkat kabupaten/kota, provinsi, dan bahkan nasional. Kalau anda tadi mengatakan batubara lagi batubara lagi. Ada sudah aturannya bahwa hasil dari tambang itu juga memberikan bagian ada di provinsi, ada kabupaten/kota, ada dibagi ke seluruh kabupaten/kota. Jadi memang sudah teratur, sudah terarah. Saya tidak habis pikir apa ada udang Dibalik Batu dari pernyataan-pernyataan saudara sehingga bicara terus batubara, batubara, batubara dan saya katakan bahwa hari ini sektor pertanian mengimbangi sektor batubara batubara, memberikan kontribusi $16,9 \%$ terhadap pertumbuhan ekonomi Kalimantan Selatan. Pertanian juga begitu, inilah yang dikatakan bahwa kita hari ini sedang mentransformasi sumber daya alam tak terbarukan kepada sumber daya alam terbarukan apa saja pertanian, perkebunan, kelautan, dan pariwisata. Luar biasa Kiram itu segitiga emas, dulunya kita jalan ke sana jalan kaki jalannya rusak padahal dia dekat dengan pusat kota. Begitu termarjinalkan masyarakat di sana hanya 17 kilometer dari kantor dari pusat kota tapi masyarakat hari ini Alhamdulillah jalannya sudah mulus terima kasih." (H. Sahbirin Noor, S.Sos., M.H.: Sesi 5, Debat Pilgub Kalsel Putaran 3)

Pada data di atas, teknik-teknik yang digunakan, meliputi teknik induktif, teknik deduktif, teknik sebab-akibat, teknik narasi, teknik analogi, teknik klimaks, teknik menjelaskan dasar sebelum atau sesudah pernyataan. Namun dari ketujuh teknik tersebut, penutur cenderung menggunakan teknik menjelaskan dasar sebelum atau sesudah 
pernyataan. Itu terbukti dari jumlah data yang menggunakan teknik tersebut lebih banyak dibandingkan dengan teknikteknik lainnya.

\subsection{Pemilihan Kata}

\subsubsection{Penggunaan kata yang jelas}

Ditinjau dari aspek penggunaan

kata ditemukan bahwa penutur menerapkan aspek-aspek pemilihan kata, meliputi penggunaan kata yang jelas, penggunaan kata yang tepat, dan penggunaan kata yang menarik atau hemat. Ditinjau dari aspek penggunaan kata yang jelas, Sudiana (2007: 129) menyatakan bahwa kejelasan kata dapat diusahakan dengan tiga cara, yakni menggunakan kata-kata yang spesifik, menggunakan kata-kata sederhana, dan menggunakan kata secara hemat. Sejalan dengan teori yang disampaikan, penutur sudah menerapkan tiga cara tersebut untuk menyatakan kejelasan kata. Namun, dari tiga cara itu, penutur cenderung menggunakan kata secara hemat. Itu terbukti dari jumlah data yang menggunakan kata secara hemat paling banyak dibandingkan dengan cara lainnya, berikut ini adalah salah satu contoh penggunaan kata yang hemat.

"Kalimantan Selatan ke depan yaitu sumber daya spiritual (spiritual resources), sumber daya alam (natural resources) dan sumber daya manusia. Inilah tiga pilar yang akan menuju Kalimantan Selatan ke depan yang lebih beriman lebih unggul dan lebih makmur kenapa demikian Kalimantan Selatan" (Prof. H. Denny Indrayana, S.H., LL.M., Ph.D.: Sesi 3, Debat Pilgub Kalsel Putaran 3)

Pada data di atas, pernyataan yang disampaikan oleh pembicara menggunakan kata-kata secara hemat karena pernyataannya dapat dipahami dan tidak menggunakan kata secara berlebihan.

\subsubsection{Penggunaan Kata yang Tepat}

Ditinjau dari aspek penggunaan kata yang tepat, Sudiana (2007: 132) dan Rakhmat (2012: 49) menyatakan ada beberapa prinsip yang diperlukan dalam menggunakan kata-kata yang tepat, yakni hindari penggunaan kata-kata klise, gunakan bahasa pasaran secara hati-hati, hati-hati dalam menggunakan kata-kata pungut, hindari penggunaan kata-kata vulgar dan yang kurang sopan, jangan menggunakan eufimisme yang berlebihan. Berdasarkan teori tersebut, penutur (calon gubernur) sudah menerapkan prinsipprinsip penggunaan kata yang tepat. Dari keseluruhan tuturan yang diperoleh, calon gubernur tidak menggunakan kata-kata klise dalam menyampaikan tuturannya, tidak menggunakan bahasa pasaran, tidak menggunakan kata-kata vulgar dan kurang sopan, serta tidak menggunakan eufimisme yang berlebihan sedangkan dilihat dari penggunaan kata-kata pungut, calon gubernur dikategorikan telah berhati-hati dalam memilih kata pungut 
atau kata yang diserap dari bahasa asing karena penggunaannya sesuai dengan konteks pernyataan. Berikut ini adalah salah satu contoh penggunaan kata yang tepat.

"Kami akan memberikan kesempatan lebih bagi nelayannelayan kecil termasuk menyediakan alat tangkap bagi mereka sehingga bisa mendapatkan rezeki" (Prof. H. Denny Indrayana, S.H., LL.M., Ph. D: Sesi 2, Debat Pilgub Kalsel Putaran 3).

Tuturan di atas telah memenuhi kriteria penggunaan kata yang tepat karena sudah memenuhi kelima kriteria penggunaan kata yang tepat. Pada tuturan tersebut tidak ditemukan penggunaan kata-kata klise dan tidak menggunakan bahasa pasaran. Pada data tersebut ditemukan kata serapan dari bahasa Latin Yunani, yakni "program" yang dicetak tebal, tetapi penggunaan kata tersebut sesuai dengan konteks pembicaraan sehingga pembicara dianggap sudah berhati-hati dalam menggunakan kata serapan/kata pungut karena kata program bermakna rancangan atau hal yang akan digunakan. Pada data tersebut juga tidak ada penggunaan kata-kata vulgar dan yang kurang sopan serta penggunaan eufemisme secara berlebihan.

\subsubsection{Penggunaan Kata yang Menarik}

Ditinjau dari aspek penggunaan kata yang menarik, Sudiana (2007: 135) dan Rakhmat (2012: 50) menyatakan bahwa ada beberapa hal yang perlu diperhatikan dalam penggunaan kata yang menarik, yakni pilih kata yang langsung menyentuh diri mitra tutur, gunakan kata yang berona, dan gunakan kata-kata tindak (action word). Pada penelitian ini tuturan yang disampaikan oleh calon gubernur sudah menggunakan kata yang menarik, meliputi pemilihan kata yang langsung menyentuh diri mitra tutur, menggunakan kata yang berona, dan menggunakan kata-kata tindak (action word). Dari tiga indikator pemilihan kata yang menarik, hasil penelitian ini menunjukkan bahwa calon gubernur cenderung menggunakan katakata tindak (action word) dalam menyampaikan tuturan. Berikut ini adalah salah satu contoh penggunaan kata tindak (action word).

"Terkait dengan bidang-bidang yang tadi kita diskusikan itu akan berpihak kepada kaum-kaum yang memang termarjinalkan itu akan terlihat dalam anggaran dan itu akan terealisasi dalam program-program." (Prof. H. Denny Indrayana, S.H., LL.M., Ph. D: Sesi1, Debat Pilgub Kalsel Putaran 3)

Pada data di atas, penggunaan kata tindak (aktif) "berpihak" membuat pernyataan menjadi lebih menarik dan bertenaga dibandingkan dengan menggunakan kata tanggap (pasif).

\section{Penutup}

\subsection{Simpulan}

Berdasarkan rumusan masalah yang dipilih terkait dengan pengorganisasian tuturan dan pemilihan kata Debat Calon 
Gubernur dan Wakil Gubernur Kalimantan Selatan Tahun 2020 dapat simpulan bahwa pengorganisasian tuturan, calon gubernur telah menerapkan empat aspek pengorganisasian tuturan, meliputi:

1) Organisasi tuturan (bagian awal, tengah, akhir).

2) Prinsip organisasi tuturan (prinsip kesatuan, koherensi, dan penekanan).

3) Pola organisasi tuturan (pola topikal, pemecahan masalah, dan sebabakibat).

4) Pengembangan tuturan (teknik teknik induktif, deduktif, sebab- akibat, narasi, analogi, klimaks, dan menjelaskan dasar sebelum atau sesudahpernyataan).

Pemilihan kata, calon gubernur menerapkan tiga aspek pemilihan kata dalam bertutur, meliputi:

1) Penggunaan kata yang jelas (spesifik, sederhana, hemat).

2) Penggunaan katayang tepat.

3) Penggunaan kata yang menarik (menyentuh diri mitra tutur, menggunakan kata berona, dan menggunakan kata tindak).

\subsection{Saran}

Berdasarkan hasil penelitian dan simpulan di atas, ada beberapa hal yang dapat peneliti sarankan.

1) Bagi masyarakat umum, hasil penelitian yang meliputi pengorgani- sasian tuturan dan pemilihan kata ini dapat digunakan sebagai contoh cara bertutur efektif agar tuturan yang disampaikan mudah dipahami oleh mitratutur.

2) Peneliti berikutnya diharapkan dapat melakukan penelitian sejenis dengan memperluas jangkauan penelitian, seperti bahasa figuratif dalam bertutur dan gaya retorika nonkebahasaan.

\section{Daftar Pustaka}

Ardiansyah, M. F. 2017. Analisis Retorika Basuki Tjahaja Purnama dalam Kampanye Rakyat Pemilihan Kepala Daerah Khusus Ibukota Jakarta di Rumah Lembang 2017. e-Journal Pendidikan Bahasa dan Sastra Indonesia, Unes Volume: Vol: 1 No: 1 Tahun: 2017

Chaer, A. 2010. Pengantar Semantik Bahasa Indonesia. Jakarta: Rineka Cipta.

Effendy, O. U. 2012. Dimensi-Dimensi Komunikasi. Bandung: Remaja Rosdakarya.

Humaidi, A. 2016. Struktur Teks, Kognisi Sosial, dan Dimensi Sosial Pidato Susilo Bambang Yudhoyono. e-Journal Bahasa, Sastra, dan Pembelajarannya, Ulm, Volume: Vol: 6 No: 1 Tahun: 2016

Jamaludin, M. Y. 2013. Tuturan Guru dalam Pembelajaran Bahasa Indonesia di Kelas XI SMA Negeri 1 Selong Ditinjau dari Retorika. e- Journal Program Pascasarjana Universitas Pendidikan Ganesha, Volume 12. 
Retorika dalam Debat...

Keraf, G. 2012. Diksi dan Gaya Bahasa. Jakarta: Gramedia Pustaka Utama.

Kusmiati, M. L, dkk. 2017. Analisis Retorika Calon Gubernur Pada Debat Pemilihan Gubernur DKI Jakarta Tahun 2017. e-Journal Pendidikan Bahasa dan Sastra Indonesia, Undiksha Volume: Vol: 7 No: 2 Tahun: 2017

Martha, I. N. 2012. Pengantar Retorika. Singaraja: Universitas Pendidikan Ganesha.

Moleong, L. J. 2014. Metodologi Penelitian Kualitatif. Bandung: Remaja Rosdakarya.

Pangaribuan, T. 2013. Paradigma Bahasa. Yogyakarta: Graha Ilmu.

Primasiwi, A. 2011. Teori Komunikasi. Jakarta: Gramedia Pustaka Utama.

Sudaryanto. 2015. Metode dan Aneka Teknik Analisis Bahasa. Yogyakarta: Sanata Dharma University Press.

Sudiana, I. N. 2007. Retorika Bertutur Efektif. Sidoarjo: Penerbit Asri Press.

Sugiyono. 2009. Metode Penelitian Kuantitatif Kualitatif dan $R \& D$. Bandung: Alfabeta.
Tasmara, Toto. 2014. Retorika Bahasa. Jakarta: Gramedia Pustaka Utama. 